\title{
SUSTAINABLE POLICIES TO IMPROVE URBAN ECOSYSTEM RESILIENCE
}

\author{
R. DE LOTTO, G. ESOPI \& S. STURLA \\ Department of Civil Engineering and Architecture, UPLab, University of Pavia, Italy.
}

\begin{abstract}
In the contemporary debate about key issues of urban science (sustainability, environment, governance, etc.) resilience has a fundamental role. It is defined as the ability of a complex system to cope with external stresses through adaptation and mutation strategies and to return to an equilibrium state (not necessarily equal to the original one). In particular, ecosystem resilience is based on the concepts of diversity (biodiversity), redundancy (ecological variability), cycles of adaptation (multiple equilibrium states), and interaction between spatial scales (hierarchy) and temporal (activation of different times responses). In an urban context with high soil sealing, such as historical centers, it is essential to find new methods and application techniques that will be able to integrate the use of natural solutions with artificial ones and increasing ecosystem resilience and urban ecological quality. In fact, in these contexts, the percentage of permeable and green public areas available is not capable of performing ecosystem functions: so, it is necessary to act on private property through green punctual interventions (such as green roofs and walls), that may become fundamental elements of the municipal ecological network. In fact, these actions bring benefits from several points of view (environmental, economic, building comfort, etc.) The aim of the paper is to study the relationship between technical aspects and urban policies, and, in particular, to resolve the main question: how to encourage private owners to invest in green interventions for improving buildings' efficiency and environmental quality? In this process it is important to define sustainable policies acting on private property that consider both individual and global interests. Further, the article focuses on different case studies and examples taken from the United States with the objective to define similar policies in the Italian context.
\end{abstract}

Keywords: ecosystem resilience, green infrastructure, sustainable policies.

\section{INTRODUCTION}

Resilience is the capacity of complex systems to cope with external stresses through adaptation and mutation strategies and to return to an equilibrium state (not necessarily equal to the original one). In other terms, resilience is an 'autonomous adaptation that responds as conditions change' [1]. To be resilient, an urban system must possess the following features: to pursue a balanced and sustainable development model based on integration of social, environmental, and economic issues; to preserve and to enhance local resources; to reduce environmental impacts due to human phenomena (industrial systems, fuel pollution, etc.) and to encourage social participation both in the planning phase and in the management phase. From an ecological point of view, a resilient city must react to environmental shocks (climate change, flooding, etc.) protecting biodiversity and natural ecosystems. This capacity to adapt is defined exactly as ecosystem resilience that is based on the concepts of diversity (biodiversity), redundancy (ecological variability), cycles of adaptation (multiple equilibrium states), and interaction between spatial scales (hierarchy) and temporal (activation of different times responses) [2, 3]. It is expressed through planning policies that will be able to manage and to mitigate environmental impacts. 
To optimize ecosystem resilience of human settlements, adaptation strategies, such as mitigation of climate changes effects and contrast of hydrogeological instability, are necessary to restore environmental functions.

A possible solution is the construction of networks with ecological value: the green infrastructures.

\section{GREEN INFRASTRUCTURE FOR URBAN RESILIENCE}

The infrastructures are 'basic systems and services, such as transport and power supplies, that a country or organization uses in order to work effectively' [4] and they can be divided into linear elements (roads, sewers, utility lines, etc.) or punctual elements (hospitals, schools, public bureaus, etc.). Green infrastructure is an advanced type of infrastructure that is crucial for the continuance and growth of a community. Initially, the term was referred to parklands, forests, wetlands, greenbelts, or floodways in and outside cities that improve quality of life and provide ecosystem services. Today, it also includes the system of small and punctual green elements such as green roofs and walls, soft permeable surfaces, green streets and avenues, green open spaces, and all the ecological interventions adopted by cities in order to achieve environment and sustainability objectives. Green infrastructure is defined as a - 'network of multi-functional green spaces, both newly identified and existing, both rural and urban, that supports natural and ecological processes. It is a fundamental component for community health and quality of life' [5]. A main feature that distinguishes green infrastructure from ecological network is its multi-functionality: in fact it combines both ecosystemic and functional aspects (recreation, open space, mobility, etc.). Green infrastructure is a network of natural and restored ecosystems consisting of nodes and links. The nodes, the punctual elements of the system, represent the origins and destinations of ecological flows (reserves, managed native landscapes, working lands, regional parks, and community parks); the links are linear elements that connect different nodes (landscape linkages, ecological corridors, greenways, and greenbelts). Connectivity is a key component of the system and allows its operation effectively: the connections are not necessarily physical and direct but also visual. A connected system of green areas and parks is more complete and useful than a series of isolated parks [6-13].

As compared to traditional grey infrastructures that perform a single function such as transport or urban drainage, green ones integrate within them different functions (transport, recreation, open spaces) reducing the impact on territories and providing other environmental benefits (biodiversity conservation, climate mitigation, and environmental quality improvement).

The addition of green infrastructures can improve ecosystem resilience and ecological quality of urbanized and rural areas. In particular, in an urban context with high density, high soil sealing, and high coverage ratio, it is possible to increase ecological value through green widespread interventions at different scales, from metro regions (regional parks) and entire cities (urban parks) to neighborhoods (neighborhoods and pocket parks) and individual buildings (green roof and wall and other green solutions that can be inserted in urban texture or in buildings' shape). The ecological strategies can be implemented through public projects or can be applied on private property. At the local scale, these green elements may become part of the municipal ecological network: in fact, they act on urbanized fabrics such as stepping stones and, if properly aligned, they can replace to a certain extent a continuous corridor [14]. The actions bring several environmental, social, and economic benefits: maintenance of natural landscape processes, attenuation of heat island effect, absorption of pollutants (such as $\mathrm{CO}_{2}$ ) and of excess surface water reducing floods risk, better connection to nature and sense of place, and increased recreational opportunities. The extensive use of artificial green infrastructures improves quality of life, beauty of the urban landscape and attractiveness of the city. 


\section{ECOPOLICIES AND CITY PLANNING}

Ecopolicies may be divided into two main fields: reduction of energy consumption (and renewable energy production) and green interventions (that involve water treatment, evapotranspiration, absorption of pollutants, etc.).

Energy sector and environmental policies are inextricably linked.

Traditional energy consumption has different impacts on the environmental components and one of the main goals of environmental sustainability is to reduce energy consumption that can be actuated actively through the use of renewable sources or passively through the energy efficiency of buildings (building zero emission or passive houses).

The building sector is the largest contributor to global GHG emissions.

Buildings use about $40 \%$ of global energy, $25 \%$ of global water, and $40 \%$ of global resources, and they emit approximately $1 / 3$ of global GHG emissions.

Existing buildings represent significant energy-saving opportunities because their performance level is frequently far below current efficiency potentials [15].

A key policy instrument that can assist governments in reducing energy consumption and producing renewable energy in the building sector is the Energy performance certification. It provides objective information on a given building and is a valid tool for the building industry and the private property marketplace because it shows the level of energy performance andcan be compared to other similar buildings.

For example, in an Italian context, energy performance certification rating is from $G$ (very poor) to A (very good) depending on the $\mathrm{KWh} / \mathrm{y}$ for each square meter consumed and on the quantity of produced renewable energy.

Apart from the specific range, the advantages associated with high Energy performance certification are:

- energy and $\mathrm{CO}_{2}$ emissions reductions;

- increased public awareness of energy and environmental issues;

- lower costs for users.

Environmental policies for green interventions are important instruments to improve environmental quality in city planning and, the application of specific indexes, in particular, is another key policy instrument that can measure the ecological value of the area under examination.

In literature, there are many ecological indexes that have been applied on new projects or for redeveloping existing ones.

Biotope Area Factor was the first index pioneered in the city of Berlin in the past decade. It measuresthe ecological value of the green area and includes both natural elements and artificial ones.

The ecological value depends on the percentage of permeability and evapotranspiration of the surface [16].

From a city planning point of view, there are many variables that might be considered. Considering urban fabric density, the lower the density, the better the potential performance in terms of BAF; with regard to urban fabric coverage ratio, the lower the coverage ratio the higher the potential BAF.

Combining the two factors, it is quite obvious that a typical villas fabric is suitable to have good BAF parameters. But, at the same time, this typology implies high soil consumption, and, therefore, the global effects may be not desirable.

From land use point of view, some different functions can be easily inserted in buildings' shapes with the usual high covered ratio (offices, services, facilities, welcome centers, 
commercial facilities, etc.), while other functions (in particular the residential one) are more related to specific building typologies that usually have a lower covered ratio.

So, for some urban functions there is a higher probability of having a low BAF performance while others are more efficient.

From the property system point of view, the higher the fragmentation of lots or ownerships inside one building, the higher the difficulty in finding a solution as jointly agreed.

From the landscape point of view, the improvement of green area has positive effects only where the urban landscape sensitivity is already made of the relationship between buildings and green area (small density settlements and non-historical area/settlements. In a historical center (i.e. in a European context or, with more detail, in an Italian context) the urban landscape is strictly related to building features that may not admit green elements - roofs or walls - as real improvements [17].

\section{SUSTAINABLE POLICIES FOR ECOLOGICAL INTERVENTIONS: EXAMPLES FROM THE UNITED STATES}

To realize widespread green infrastructures within high density and high coverage ratio neighborhoods, efficient urban policies are necessary, which must act on public areas and also on private property, considering global and individual interests. These policies must offer benefits to stakeholders for the construction of interventions with ecological value (green roofs and walls, increasing the permeable surface, etc.). Some examples of incentives adopted by American cities are provided in the following text.

4.1 Mechanism for financing energy efficiency and renewable energy improvements on private property

An important funding mechanism implemented in the United States to encourage energy and environmental sustainability of private building is Property Assessed Clean Energy (PACE).

The Pace program is an efficient way to improve energy efficiency and renewable energy in a private building because it pays for $100 \%$ of a project's costs and is repaid by owners for up to 20 years with an assessment added to the property's tax bill.

Pace is a debt of property, meaning the debt is tied to the property as opposed to being tied to the property owner.

It means that the repayment obligation may transfer with the property ownership.

The strengths of this program are:

- abatement of initial spending costs for energy improvement;

- property acquired at higher market value;

- property owners deduct payments from their income tax liability;

- the debt is on the property.

Currently, PACE has been adopted by 31 states in the United States [18].

4.2 Legislation, policies and tax incentives

Government incentives are fundamental catalysts for the development of environmental sustainability and, in particular, for green infrastructure (natural or artificial).

It is possible to recognize two implementation policies: 
- Direct financial incentives such as grants and subsidies;

- Indirect financial incentives such as fee reductions, floor space density bonuses, regulations, and standards.

Table 1: Urban policies and initiatives proposed by cities in North America.

\begin{tabular}{|c|c|c|c|}
\hline City & $\begin{array}{l}\text { Policies } \\
\text { initiative }\end{array}$ & BONUS & $\begin{array}{l}\text { Direct or } \\
\text { indirect } \\
\text { policies }\end{array}$ \\
\hline $\begin{array}{l}\text { Austin } \\
\text { (Texas) }\end{array}$ & $\begin{array}{l}\text { Green Roof } \\
\text { Density Bonus }\end{array}$ & $\begin{array}{l}\text { Square feet of bonus floor for each one } \\
\text { square foot of green roof installed [19] }\end{array}$ & indirect \\
\hline $\begin{array}{l}\text { Baltimore } \\
\text { (Maryland) }\end{array}$ & $\begin{array}{l}\text { Baltimore } \\
\text { Stormwater } \\
\text { Management } \\
\text { Incentive }\end{array}$ & $\begin{array}{l}\text { Stormwater fee for residential and } \\
\text { commercial properties (with less than } 820 \\
\text { square feet of impervious surface fee of } \\
\$ 10 / \text { quarter, } 820-1,500 \text { square feet at } \$ 15 \text { / } \\
\text { quarter, and more than } 1,500 \text { square feet } \\
\text { at } \$ 30 / \text { quarter) [20] }\end{array}$ & indirect \\
\hline $\begin{array}{l}\text { Chicago } \\
\text { (Illinois) }\end{array}$ & $\begin{array}{l}\text { Floor Area Ratio } \\
\text { (FAR) Bonus }\end{array}$ & $\begin{array}{l}\text { FAR bonus for developments (including } \\
\text { a green roof that covers } 50 \% \text {, or } \\
2,000 \text { square feet of the roof area) [21] }\end{array}$ & indirect \\
\hline $\begin{array}{l}\text { Indianapolis } \\
\text { (Indiana) }\end{array}$ & $\begin{array}{l}\text { Indianapolis Green } \\
\text { Roof Incentive }\end{array}$ & $\begin{array}{l}\text { Grants awarded to organizations who use } \\
\text { green infrastructure to improve water } \\
\text { quality and reduce storm water runoff [22] }\end{array}$ & direct \\
\hline $\begin{array}{l}\text { Milwaukee } \\
\text { (Wisconsin) }\end{array}$ & $\begin{array}{l}\text { Green } \\
\text { Infrastructure } \\
\text { Partnership } \\
\text { Program }\end{array}$ & $\begin{array}{l}\text { Funding of as much as } \$ 54 / \mathrm{m} 2(\$ 5 / \mathrm{ft} 2) \\
\text { of approved green roof projects within its } \\
\text { service area [23] }\end{array}$ & direct \\
\hline $\begin{array}{l}\text { Minneapolis } \\
\text { (Minnesota) }\end{array}$ & $\begin{array}{l}\text { Minneapolis } \\
\text { Stormwater Credit } \\
\text { Program }\end{array}$ & $\begin{array}{l}\text { Credit of up to } 50 \% \text { off of the city's } \\
\text { stormwater utility fee to buildings } \\
\text { to improve stormwater management } \\
\text { practices [24] }\end{array}$ & indirect \\
\hline $\begin{array}{l}\text { New York City } \\
\text { (New York) }\end{array}$ & $\begin{array}{l}\text { Green } \\
\text { Infrastructure } \\
\text { Grant Program }\end{array}$ & $\begin{array}{l}\text { Funds for private property owners } \\
\text { for design and construction of green } \\
\text { infrastructure systems [25] }\end{array}$ & direct \\
\hline Ohio State & $\begin{array}{l}\text { Alternative Storm } \\
\text { water Infrastructure } \\
\text { Loan Program }\end{array}$ & $\begin{array}{l}\text { Below-market rate loans for design and } \\
\text { construction of green infrastructure [26] }\end{array}$ & direct \\
\hline $\begin{array}{l}\text { Philadelphia } \\
\text { (Pennsylvania) }\end{array}$ & $\begin{array}{l}\text { Green Roofs Tax } \\
\text { Credit }\end{array}$ & $\begin{array}{l}\text { The city offers a } 25 \% \text { (Business Privilege } \\
\text { Tax) of all costs incurred for installation } \\
\text { of green roof up to a maximum of } \\
\$ 100,000[27]\end{array}$ & indirect \\
\hline
\end{tabular}


Table 1: (Continued)

\begin{tabular}{|c|c|c|c|}
\hline City & $\begin{array}{l}\text { Policies } \\
\text { initiative }\end{array}$ & BONUS & $\begin{array}{l}\text { Direct or } \\
\text { indirect } \\
\text { policies }\end{array}$ \\
\hline $\begin{array}{l}\text { Portland } \\
\text { (Oregon) }\end{array}$ & $\begin{array}{l}\text { Portland's Ecoroof } \\
\text { Program }\end{array}$ & $\begin{array}{l}\text { An incentive of } \$ 5 \text { per square foot is } \\
\text { offered to property owners and developers } \\
\text { of ecoroof construction [28] }\end{array}$ & direct \\
\hline $\begin{array}{l}\text { Portland } \\
\text { (Oregon) }\end{array}$ & $\begin{array}{l}\text { Clean River } \\
\text { Rewards Storm } \\
\text { water Discount } \\
\text { Program }\end{array}$ & $\begin{array}{l}100 \% \text { discount on management charges } \\
\text { to promote storm water management } \\
\text { practices [29] }\end{array}$ & indirect \\
\hline $\begin{array}{l}\text { Seattle } \\
\text { (Washington) }\end{array}$ & FAR Bonus & $\begin{array}{l}\text { An extra } 3 \text { square feet of bonus floor per } \\
\text { square foot of green roof constructed }\end{array}$ & indirect \\
\hline $\begin{array}{l}\text { Syracuse } \\
\text { (New York) }\end{array}$ & $\begin{array}{l}\text { Onondaga } \\
\text { County Green } \\
\text { Improvement Fund }\end{array}$ & $\begin{array}{l}\text { Financial assistance for green } \\
\text { infrastructure projects installation [30] }\end{array}$ & direct \\
\hline $\begin{array}{l}\text { Toronto } \\
\text { (Canada) }\end{array}$ & $\begin{array}{l}\text { EcoRoof Incentive } \\
\text { Program }\end{array}$ & $\begin{array}{l}\text { Funds from } \$ 75 / \text { square meter up to a } \\
\text { maximum of } \$ 100,000 \text { for green roof } \\
\text { projects [31] }\end{array}$ & direct \\
\hline
\end{tabular}

Several cities have implemented incentive policies to promote environmental sustainability. Table 1 shows an overview of policies and initiative proposed.

These government incentives demonstrate that the generated benefits, previously described, are an important start point for the 'new urban development', and these projects have competitive advantage in the sustainable green building market.

\section{EUROPEAN POLICIES AND ITALIAN CONTEXT}

In the past few years, the European Commission adopted the Strategy on Green Infrastructure to support the improvement of natural processes within territorial planning. In particular, the objectives of the strategy are:

- to promote green infrastructure in main policies (mitigation and adaptation to climate change, transport, energy, disaster prevention and land use, social cohesion);

- to improve research and data, enrich knowledge, and promote innovative technologies in support of green infrastructures;

- to facilitate financing access for green infrastructures projects;

- to support green infrastructures projects.

Recently, some Italian cities adopted policies to subsidize the cost of establishment and deployment of green infrastructures. The municipalities of Rimini and Florence provide economic incentives (reduction of secondary infrastructure expenses) compared with interventions of horizontal and vertical green. The following year, Bolzano assigned to green covers a coefficient (from 0.20 to 1.00 ) to achieve a quality step for obtaining planning permission. 
In 2015, the Italian Senate drafted a bill that offered tax benefits (deduction of $36 \%$ for green accommodation of private areas for expenses from 2,000 to 30,000 euros and from 5,000 to 50,000 euros for blocks) to combat landscape degradation. The private garden brings benefits to urban microclimate and inserts green elements in gray contexts. The deduction is provided for accommodation and maintenance costs.

In Italy, the main problem for every policy connected to the building sector is the actual situation of the crisis. Real estate and development crisis carried to scenarios in which it is difficult to forecast indirect or direct financial policies.

Indirect policies, that act at the local scale, may generate a minor income of local taxes from the building sector; once the sector stands still and there are no forecasts of developments, it is difficult for a Municipality when it has to give up possible incomes - some kind of bonus that may not have enough value to level off the investment in green performance. This happens because of thedifficulty to evaluate precisely the value of buildable volumes. Therefore, the advantage is not easily measurable. For example, a reduction of public facilities (or standards) that is an obligation of Municipalities involved in a difficult economic period could pose a disadvantage.

The direct policy made of grants is mainly a local policy that involves development rights that can be transferred inside the territory of a Municipality. Nowadays, it is difficult to have efficient application of transfer development rights from plot sites in different districts.

The direct policies based on subsidies may have a better possibility to be effective, because they can act at a bigger scale (Regional and National) and because they involve lending institutions and banks. On the other hand, it is well known that subsidy policies are effective only in the short term, in order to overcome a sudden or short crisis.

So, pure direct or indirect policies do not seem to be effective: it is necessary to find a proper mix of direct and indirect financial incentives in order to overcome the actual crisis and to strengthen the intervention for green infrastructures in the mid- and long-term.

\section{CONCLUSION}

For what has been stated, investments on green infrastructures are absolutely necessary for the future of the city in terms of quality of life and a healthier urban environment. Considering that green infrastructures are made of natural elements and built environment, the actual chance is to improve the quality of built spaces. It is well known that, in quite every city worldwide, the majority of built environment is on private property, and therefore, a strategy based on specific intervention that is feasible in private lots must be found. Every kind of 'green' intervention involves a significant economical investment that might be compensated with reduction of expenses (in case of buildings, energetic performance improvements) or with specific public policies that include direct and indirect financial benefits. The actual real estate and development crisis forces an integration between these two kinds of interventions because the policy is effective only if it creates long-term benefits. In the Italian context, it is necessary to define proper policies that can be applied in parts of the city with high density and high covered ratio (where parameters as Biotope Area Factor are particularly low) but the landscape sensitivity of a specific context such as historical centers must be considered. Another aspect that must be considered is the fragmentation of properties, which is more diffuse in residential contexts with medium and high density; so the policy must consider different benefits that have immediate impact on all involved subjects. Looking at worldwide applications and case studies, and considering the effectiveness of specific and composed policies, facts demonstrate that green infrastructures can be improved in private properties as well. 


\section{REFERENCES}

[1] Center for Clean Air Policy, The value of green infrastructure for urban climate adaptation, available at www.ccap.org, 2011.

[2] Newman, P., Resilient Cities, 2010, available at http://espace.library.curtin.edu.au

[3] Colucci, A., Le città resilienti: approcci e strategie, Jean Monnet Interregional Centre of Excellence: University of Pavia, 2012.

[4] Cambridge Dictionaries Online, Infrastructure, available at http://dictionary.cambridge.org

[5] Planning Policy Statement, Policy 12, Local Spatial Planning.

[6] Akbari, H., Shade trees reduce building energy use and $\mathrm{CO}_{2}$ emission from power plants. Environmental Pollution, 116, pp. 119-126, 2002. http://dx.doi.org/10.1016/S0269-7491(01)00264-0

[7] Benedict, M.A. \& McMahon E.T., Green Infrastructure: Smart Conservation for the 21 st Century, Sprawl Watch Clearinghouse: Washington DC, 2006.

[8] Camagni, R., Capello, R. \& Nijkamp, P., Towards sustainable city policy: an economyenvironment technology nexus. Ecological Economics, 24, pp. 103-118, 1998. http://dx.doi.org/10.1016/S0921-8009(97)00032-3

[9] Capello, R., Nijkamp, P. \& Pepping, G., Sustainable Cities and Energy Policies, Springer-Verlag Publisher: Berlin, 2010.

[10] European Commission, Building Green Infrastructure, available at http://ec.europa.eu 2013.

[11] Fusco Girard, L. \& Nijkamp, P., Le valutazioni per lo sviluppo sostenibile della città e del territorio, Franco Angeli Publisher: Milano, 1997-in Italian.

[12] Rouse, D.C. \& Bunster-Ossa, I.F, Green Infrastructure: A Landscape Approach, Planning Advisory Service, 571, American Planning Association: Chicago, 2013.

[13] Steiner, F., The Living Landscape: An Ecological Approach to Landscape Planning, McGraw Hill Professional Publisher: Milan, 2000.

[14] Peraboni, C., Reti ecologiche e infrastrutture verdi, Maggioli Publisher: Milan, 2010.

[15] Communication from the Commission to the European Parliament and the Council Energy Efficiency and its contribution to energy security and the 2030 Framework for climate and energy policy, Brussels, 2014.

[16] International Energy Agency, Energy Performance Certification of Buildings: a Policy Tool to Improve Energy Efficiency, France, 2010.

[17] De Lotto, R. \&M.L. Di Tolle, Elementi di progettazione urbanistica-rigenerazione urbana nella città contemporanea, Maggioli Publisher, 2013.

[18] PACE Nation, available at http://www.pacenation.us/about-pace

[19] Austin Texas Government, Green Roofs, available at http://www.austintexas.gov, 2011.

[20] Baltimore Government, Stormwater Management, available at http://publicworks. baltimorecity.gov

[21] Chicago Government, Floor area bonuses, available at http://chicagocode.org

[22] European Commission, Green Infrastructure, available at http://ec.europa.eu, 2010.

[23] Green innovation for smart cities, Green roof Incentives, available at http://www. vegetalid.us, 2015.

[24] Indianapolis Government, Green Infrastructure Grant Program, available at http://www. indy.gov, 2011.

[25] Minneapolis Government, How can you reduce your stormwater fee? available at http:// www.minneapolismn.gov, 2013. 
[26] New York Government, Grant Program for Private Property Owners, available at http:// www.nyc.gov, 2015.

[27] Ohio Government, Community Grants, Loans, Bonds and Tax Credits, available at https://development.ohio.gov

[28] Planning Policy Statement, Policy 12, Local Spatial Planning, available at http://www. planningportal.gov.uk

[29] Plant Connection, Green Roof Legislation, Policies \& Tax Incentives, available at http:// myplantconnection.com

[30] Portland Government, Environmental Services, available at http://www.portlandoregon.gov

[31] Seattle Government, Green building, available at http://www.seattle.gov

[32] Toronto Government, Grants, Incentive \& Tips, available at http://www1.toronto.ca 